\title{
Introduction
}

Figure 0.1 plots Singapore's real Gross Domestic Product (GDP) per capita since 1900 along with the series for the United States (U.S.). ${ }^{1}$ Before independence in 1965, Singapore's real GDP per capita was growing at a pace to just maintain its relative distance to the U.S. economy. ${ }^{2}$ It then began to speed up to race towards the U.S. standard of living. Over the past 50 years, there has been a ten-fold increase in the standard of living for Singapore. Such an increase has been possible because the real GDP per capita has been growing, on average, at about five percent per annum over the past 50 years. Another way of putting it is to say that the standard of living has been doubling every 14 years. To see how remarkable a transformation can be made by maintaining a growth rate in real GDP per capita of five percent per annum, consider the experience of the U.S., the world economic leader in the 20th century. Since 1880, the U.S. economy has seen its real GDP per capita grow at an average annual rate of two percent per annum. At this rate, its standard of living has been doubling every 35 years; it, therefore, took the U.S. economy more than a century (115 years, to be precise) to see its living standard increase by a factor of 10. Singapore, however, took less than half the time that it has taken the U.S. economy to achieve a ten-fold increase in its standard of living. One reason

\footnotetext{
${ }^{1}$ The graph is plotted on a log scale so the slope of each line reflects the growth rate of real GDP per capita.

${ }^{2}$ Singapore was a British colony and attained self-government in 1959. In 1965, it became fully independent.
} 


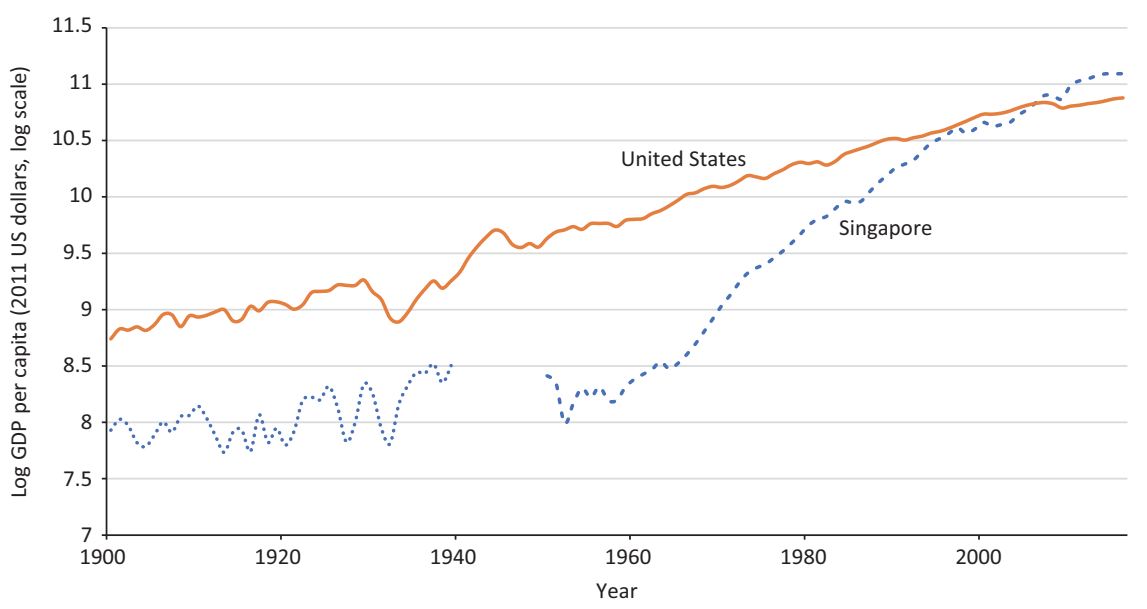

Figure 0.1: Real GDP Per Capita in the United States and Singapore, 1900-2016 Source: Maddison Project Database, version 2018. Jutta Bolt, Robert Inklaar, Herman de Jong and Jan Luiten van Zanden, 2018, "Rebasing 'Maddison': New Income Comparisons and the Shape of Long-run Economic Development," Maddison Project Working Paper, nr.10.

Singapore could achieve this is that in its economic take-off it could copy the stock of technologies available in the world (rather than reinventing the wheel). The diffusion of technology from the world's technology leader enabled Singapore to launch into a process of catchup growth. ${ }^{3}$

Given that the rise in the average person's standard of living is best described as a slow crawl from the perspective of the whole of human history, the transformation of Singapore from relative poverty as a British trading post to economic prosperity, all in a span of 50 years, is nothing short of extraordinary and is a tale worth telling. We are interested in understanding the mechanisms at work to achieve such a transformation since the income gap between rich and poor nations remains very huge. Why some countries are rich and others remain poor is a deeply important question that has major consequences for the welfare of millions of people in the world. Apart

\footnotetext{
${ }^{3}$ During the process of catch-up growth, the Singapore economy grows faster than the world's technology leader.
} 
from possible lessons the Singapore story holds for others, it also remains very important to know what the economic possibilities are for the current and future citizens of Singapore, having now surpassed the U.S. standard of living as measured by real GDP per capita. ${ }^{4}$ The approach in this book is not to provide a narrative of who did what, what worked, and what did not work. The first-generation leaders were remarkable people who saw beyond their own personal gains, faced huge obstacles, and made many sacrifices in order to make life better for their fellow countrymen. A careful study of their lives, how they came to be the sort of persons they were and made the choices they did, would be beneficial and inspiring for all of us. But that is not what this book sets out to do. Instead, its aim is to try to provide a theory of Singapore's economic development. With a coherent theory capable of explaining how we got to where we are, we might be able to use the same theory of growth to predict what the future might look like.

The book aims to develop a theoretical framework that will allow us to distil the economic (and non-economic) forces as well as the mechanisms they worked through to produce the lift from low living standards to economic prosperity. It seeks answers to questions such as: Having now reached the status of a rich country, what policy choices will we have to make in order to achieve desired outcomes in the face of new trade-offs? What predictions can we make about our economic future based on the framework we develop? In developing our framework, we go beyond the particular persons who lived in the particular historical times and made the particular decisions that affected their lives and those around them. We are interested more generally in private incentives, market forces, and their interaction with social influences and political institutions to bring about a historically unprecedented economic transformation in a relatively short span of time. We provide an analysis of how these same forces operate in a country that has completed the phase of catch-up growth and is now transiting to being a mature economy.

\footnotetext{
${ }^{4}$ The comparison of real GDP per capita is in purchasing power parity terms.
} 
It is not just individual responses to incentives that affect an economy's productivity. Broad market forces also play a big part in driving living standards as well as shape the incentives that people face and determine aggregate outcomes at an economy-wide level. When appropriate laws and institutions were put in place to guide businesses, workers, and consumers in their decision making in an environment that was fully open to the international flow of ideas, goods and capital, a catch-up process was started that we can liken to the arrival of a big wave. This wave was to carry in its wake rising living standards, jobs, and wages that were especially favourable to the less skilled so rapid growth occurred with equity in the initial phase of Singapore's economic development. ${ }^{5}$

Yet, it is not possible to understand the huge rise in Singapore's living standards without also understanding the social forces that led to the choice of the business-friendly institutions in the first place. The factors that shape good institutions have come under scrutiny by economists and political scientists in recent years as it has come to be recognised that good institutions are fundamental in explaining the wealth of nations. Social and political influences play a vital part in explaining why pro-growth institutions were established in the first place, and identifying how these influences operate is necessary for our understanding of how the Singapore economy achieved a take-off when so many other countries have remained poor despite the ready pool of world technology. It is necessary also to understand the social and economic forces that are operative in an economy that is making a transition from catch-up growth to life in a mature economy if we are to generate future economic prosperity.

Can the economic forces that were unleashed in the first big wave, the process of catch-up growth as Singapore raced towards the world technology frontier, be counted on to generate economic prosperity for Singapore in the next 50 years? In a 4 September 2001 article titled "What's new, what's next for Singapore?" published

\footnotetext{
${ }^{5}$ The phase of growth with equity ended around the year 2000. Subsequently, the gap between the earnings of high-skill workers and low-skill workers has widened. (See the discussion of wage earnings of workers at different skill levels in Chapter 2.)
} 
in The Business Times, I argued that with Singapore getting closer to the world technology frontier, growth must inevitably fall to a more moderate level that is typical among the advanced industrial economies. The same article identified three economic developments that I regarded as new for Singapore (at that point in time), each one having potentially huge socio-economic consequences. First, I argued that while the export of less-skilled-labour-intensive goods in the catch-up phase of growth raised low-skill wages and narrowed the wage gap between high-skill and low-skill workers (without the need for policy intervention such as a wage income supplement scheme for low-wage workers), economic forces would be such as to cause the wages of low-skill workers to decline in absolute and relative terms in the next stage of its economic climb. I suggested that this would come about as a result of greater competition from low-wage nations as well as from the onslaught of new technology that has a strong skill bias embedded in it. I concluded, "We have, therefore, moved from a phase of growth where economic forces tended to produce a more egalitarian society to one in which the rich tend to become richer while the poor tend to become poorer."

Second, I argued in the article that in Singapore's earlier phase of growth, actual productivity growth most likely exceeded workers' expectations. Economic growth miracles, such as the one Singapore has experienced, occur when a country that is far from the world technology frontier chooses policies that enable it to adopt the best work practices and state-of-the-art methods of production available in developed economies. I suggested in the article that "[s] uch a historically unprecedented accomplishment most likely took its participants, and economic observers, by surprise. After recording an unusually high growth rate in the catching-up phase, however, the economy must finally settle down to a more normal pace of growth in the long run." I concluded that high unemployment could result if workers do not adjust to the reality of a slower pace of growth and, accordingly, their asking wage exceeds the wage that firms can afford to pay them.

Third, I argued that while only a handful of countries adopted an outward-oriented strategy in the 1960s, many more emerging 
economies with varying levels of skill and capital endowments are now open to international flows of capital and goods. The integration of more emerging economies into the global trading system has occurred in tandem with a technological spurt that has brought down transport and communication costs. Consequently, this has led to a phenomenon variously termed as "international production disintegration" and "slicing of the value chain" where the many stages of production, from design to manufacturing of parts to assembly and then to marketing, can be carried out in different countries according to comparative costs. I concluded that "[t]his phenomenon, while posing a threat to Singapore's unskilled workers as the assembly of unskilled-labour-intensive parts move to low-wage countries, also presents new opportunities for Singapore." Among the new opportunities, I identified the middleman role that Singapore has traditionally played, which can take on a new form in the New Economy, and the stimulus to private entrepreneurship or enterprise brought about by more economies opening up and the IT revolution.

A decade and a half has passed since I wrote that article. The first decade of the 21st century saw Singapore confronting several major economic shocks: the end of the internet bubble, the SARS epidemic, and the global financial crisis of $2008-9 .^{6}$ The Singapore economy also sharply expanded the size of the foreign workforce in Singapore, especially in the second half of the decade, to take advantage of the opportunities for growth. ${ }^{7}$ The increased labour force size and concomitant inflows of foreign capital delivered some years of exceptionally high growth rates in total GDP (adjusted for inflation) and low rates of both resident and total unemployment despite the slow and negative growth in total GDP in some years.

\footnotetext{
${ }^{6}$ SARS stands for Severe Acute Respiratory Syndrome, which is a viral respiratory disease.

${ }^{7}$ The cumulative increase in total labour force size over each half decade from 1971 onwards is as follows: 1971-75 (0.16 million workers); 1976-1980 (0.26 million workers); 1981-1985 (0.09 million workers); 1986-1990 (0.36 million workers); 1991-1995 (0.19 million workers); 1996-2000 (0.44 million workers); 2001-2005 (0.18 million workers); 2006-2010 (0.77 million workers); and 2011-2015 (0.48 million workers). Source: Yearbook of Statistics Singapore, Singapore Department of Statistics, various years.
} 
The underlying forces that I identified in my 2001 article confronting Singapore are of a structural nature and might have been masked by the economic shocks and attendant policy responses to these shocks which occurred in the past decade. In this book, I seek to further develop the arguments of the 2001 article with the advantage of more than a decade worth of additional observations.

A pressing question is how to think about the sources of growth in the next decade or two? I have found that a useful way to think about Singapore's growth is to recognise that even in a well-developed economy like the U.S., not all firms operating within a narrowly defined industry are equally productive. There is a whole distribution of firmlevel productivities within an industry. The most productive firms tend to be larger, sell into overseas markets, and pay similar workers more. Work by the economists Chang-Tai Hsieh and Peter Klenow has made comparisons of these firm-level productivities for China, India and the U.S. They found wider dispersion in the productivity levels in India and China as compared to the U.S. A useful 90-10 ratio of the firm at the top decile of the productivity distribution to the firm at the bottom decile in one measure is about 1.6 in India and China compared to 1.2 in the U.S. ${ }^{8}$ Figure 0.2 illustrates a strategy to grow via narrowing the productivity dispersion of Singaporean firms within a given industry. ${ }^{9}$ This results in a rightward shift of the productivity distribution.

Growth with equity describes reasonably well the Singapore growth experience in the first three-and-a-half decades after independence. The questions that now confront us include: Has there now been an unfavourable shift of the efficiency-equity trade-off that calls for new institutional forms to underpin a new phase of strong economic performance? What sort of growth trajectory does the population need to grasp if it is to anchor its expectations realistically and thus to avert major disappointments?

\footnotetext{
${ }^{8}$ See Table II, for the year 2005, in Chang-Tai Hsieh and Peter Klenow, 2009, "Misallocation and Manufacturing TFP in China and India," Quarterly Journal of Economics, 124(4): 1403-1448.

${ }^{9}$ On the horizontal axis, we measure a firm's productivity level taken as a ratio to the industry's average productivity level.
} 


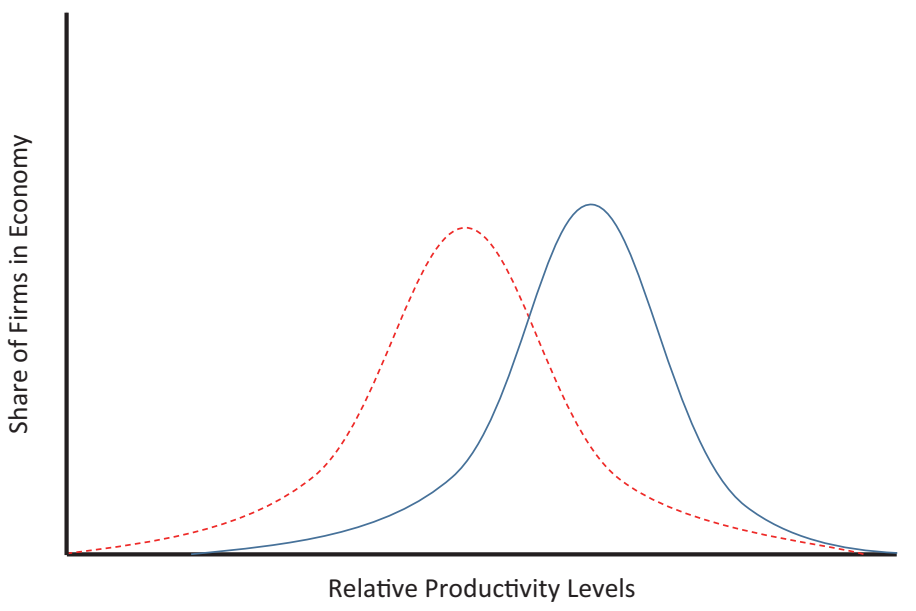

Figure 0.2: Distribution of Productivity Levels

Note: Relative productivity level is a firm's productivity level taken as a ratio to the industry's average productivity level.

There is evidence that since the turn of the century, income gaps have widened and there is a segment of Singaporeans, the bottom quintile, whose real wage earnings - wage earnings adjusted for inflation - have not caught up and, for some, actually declined. ${ }^{10}$ In 2007, the government introduced a wage subsidy scheme called a Workfare Income Supplement (WIS) scheme that would boost the wage earnings of low-wage workers in the bottom quintile of

\footnotetext{
${ }^{10}$ The Key Household Income Trends, 2010 published by the Singapore Department of Statistics reports that the GINI coefficient based on original income from work per household member increased from 0.444 in the year 2000 to 0.480 in 2010. As another measure of widening income inequality, the ratio of the average income of the top quintile of resident employed households to the bottom quintile increased from 10.1 in the year 2000 to 12.9 in 2010. A report by the Housing Development Board (HDB) provides some evidence of actual declines in real wage earnings in the past decade. Chart 3.7 of the report shows the average household monthly income from work by housing type expressed in nominal terms, that is, unadjusted for inflation. For one-room HDB flat type, the value went from $\mathrm{S} \$ 1,336$ in 1998 to $\mathrm{S} \$ 1,282$. For two-room HDB flat type, the value went from $\mathrm{S} \$ 1,691$ in 1998 to $\mathrm{S} \$ 1,718$ in 2008 . The total share of resident population living in one-room and two-room HDB flat types in 2008 was 3.4 percent. (Source: HDB Sample Household Survey 2008 titled Public Housing in Singapore: Residents' Profile, Housing Satisfaction and Preferences.)
} 


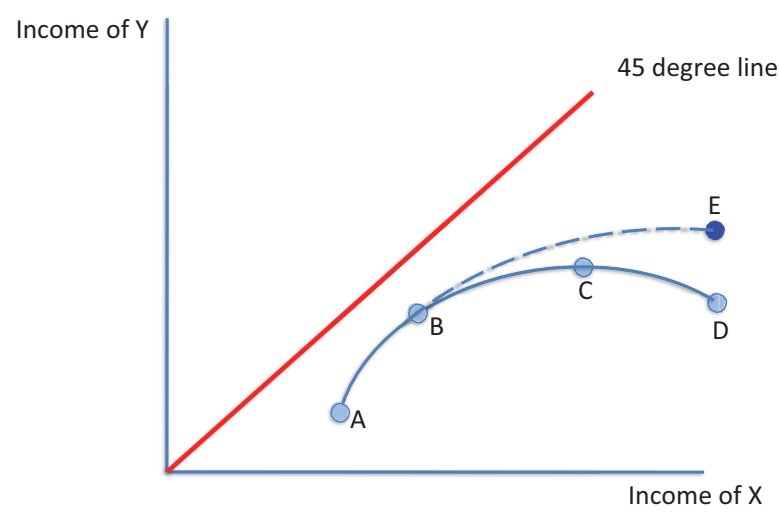

Figure 0.3: Illustration for Two Groups of Workers

the labour force. ${ }^{11}$ Figure 0.3 illustrates for two groups of workers, called low-wage group (Y) and high-wage group (X), a phase of growth during which the incomes for both groups increased along the stretch $\mathrm{ABC}$. In the segment $\mathrm{AB}$, the income of low-wage workers increases relatively faster than the income of high-wage workers so that growth occurs with a declining income gap. In the segment $\mathrm{BC}$, while incomes of both groups increase, the income of high-wage workers increases relatively faster so the income gap is widening. Since 2000, economic forces have worked in such a way as to cause an actual decline of real earnings for the low-wage group (Y) along the stretch CD. Wage income supplements given to low-wage workers can boost their take-home earnings while allowing high-wage workers to still enjoy an increase in their after-tax wage earnings. This would allow the economy to move along the stretch BE so that growth lifts up the incomes of both groups, mitigating the forces causing a widening income gap, with the wage income supplement scheme

\footnotetext{
${ }^{11}$ From 2010, workers aged 35 years and above with earnings no more that $\mathrm{S} \$ 1,700$ qualified for an income supplement on the condition that they worked for at least three months in any six-month period. The amount of WIS payment varied according to age and salary paid by the firm but the maximum amount of annual WIS payment in 2010 was $\$ \$ 2,800$. The median gross monthly income from work in 2010 was $\$ \$ 2,710$. (Source: Table 20 in Report on Labour Force in Singapore, 2010 published by the Singapore Ministry of Manpower.)
} 
financed by taxes on the high-wage group (X). Why growth occurred since 2000 with greater income inequality (accompanied by actual real wage declines for a segment of the labour force) and whether that is likely to continue in the future need to be understood for two reasons. First, we need to have a deep philosophical foundation for Singapore to implement policy measures to boost the earnings and employability of low-wage earners through its tax-subsidy system. Second, we need to determine the best policy instruments to achieve the objective.

\section{What This Book is About}

This book is about the importance of establishing economic dynamism, economic openness, and economic inclusion in the next phase of Singapore's economic development. What do we mean by economic dynamism? It is a society's ability to marshal together different stakeholders - the citizen workforce and businesses who possibly have divergent interests, to take advantage of economic opportunities while maintaining social cohesion and a stable political equilibrium. By economic openness, we mean the integration into the global economy through the international flow of ideas, goods and services, capital, and labour. Economic inclusion involves raising the pay rate of disadvantaged workers, say relative to the median wage, so that they remain deeply engaged in regular work in the formal economy.

Singapore achieved economic dynamism in the 1960s by setting up institutions that encouraged the inflow of foreign direct investments. The improvement in the industrial relations climate lowered the calculation of risks made by multinational corporations in deciding whether to base industrial production in Singapore. Prior to the arrival of the multinational corporations, the size of the manufacturing sector was limited due to financial constraints. ${ }^{12}$

\footnotetext{
${ }^{12}$ The limits placed on economic development by financial constraints, particularly in the growth of the manufacturing sector, have been emphasised by the economist Francisco Buera. See Francisco J. Buera, Joseph P. Kabuski and Yonseok Shin, 2011, "Finance and Development: A Tale of Two Sectors," American Economic Review, 101(5): 1964-2002.
} 
Local firms did not have the financial depth and access to funds to achieve the minimum scale of investment. The multinational corporations brought the needed capital as well as new markets and technology to produce for export. Once foreign firms entered, they could take advantage of the relative abundance of less-skilled workers to produce relatively less-skilled-labour-intensive goods such as textiles, garments, and simple electronics for the export market. Trade boosted the real wage earnings of less-skilled workers both in absolute terms as well as relative to the wage earnings of higherskilled workers. Market forces, therefore, worked to narrow the wage gap and thus to foster social cohesion and gain political support for integrating into the global economy. The steady inflow of foreign direct investments enabled the country to overcome credit constraints faced by domestic firms even as standard technology was imported from abroad.

Economic dynamism takes a different form when the phase of catch-up growth is over. A fundamental transition is occurring in the Singapore economy. When a big gulf existed between Singapore's actual technology level and the frontier technology in the 1960s, the advantages of relative backwardness implied that the pace of technology diffusion would be fast initially. As Singapore's technology level rose, it stimulated capital investment, which provided a further stimulus to the growth of GDP per capita. As Singapore gets closer to the technology frontier, the pace of technological diffusion slows down, thus moderating Singapore's per capita GDP growth. Domestic per capita GDP growth, however, is determined by the sum of growth based on importing technologies developed abroad and growth based on indigenous innovation. ${ }^{13}$ It is the development of indigenous innovation that can provide additional growth to the Singapore economy in its mature phase. As the stimulation of innovative activities occurs with an encouragement of startups, the economy can deliver higher growth as these startups and existing

\footnotetext{
${ }^{13}$ The importance of indigenous innovation for productivity growth in the frontier economies has been emphasised by the economist Edmund Phelps. See Edmund S. Phelps, 2013, Mass Flourishing: How Grassroots Innovation Created Jobs, Challenge, and Change, Princeton: Princeton University Press.
} 
firms improve management practices, develop new products, and break into external markets. ${ }^{14}$

Economic integration in the global flow of ideas, goods and services, capital, and labour remains necessary as it expands GDP and provides the fiscal resources to strengthen economic inclusion. Integrating into the global economy boosts GDP through several channels. As the industry expands through selling into the external market, each firm, even though small, experiences a productivity boost that allows it to expand output. For example, industry-level trade missions into the regional economies gather useful information that each firm can take advantage of to expand sales. More productive firms also self-select into selling in export markets as they are better able to afford to cover the fixed cost of establishing export platforms. Export-oriented firms are, therefore, larger. Larger firms tend to devote more resources to screen workers and improve the quality of their workforce. As a result, larger firms pay observationally equivalent workers more. Empirical evidence suggests that neighbouring countries, after adjusting for country sizes, tend to trade more with each other. ${ }^{15}$ The regional market provides an opportunity for domestic firms to gain the experience of selling abroad and learn from exporting. The experience gained can later help these firms to achieve international competitiveness to sell beyond regional markets. With a strong legal framework to support conflict resolutions, the Singapore economy has comparative advantage in producing nonstandard goods and services that are sensitive to opportunistic behaviour since it is difficult to write complete contracts. Product development is more likely to occur within such a strong legal and governance framework.

Demographic trends create headwinds even as Singapore moves to develop indigenous innovation. As wages increased from the 1960s,

\footnotetext{
${ }^{14}$ Research shows that variation in management practices contribute to persistent productivity differences across firms and countries. See Nicholas Bloom and John Van Reenen, 2010, "Why Do Management Practices Differ across Firms and Countries?" Journal of Economic Perspectives, 24(1): 203-224.

${ }^{15}$ See Robert C. Feenstra, 2016, Advanced International Trade: Theory and Evidence, second edition, Princeton: Princeton University Press.
} 
the opportunity cost of having another child also increased. While higher incomes mean that people can afford to have more children, it has been observed that the total fertility rate tends to decline as countries become richer suggesting that the substitution effect dominates the income effect of higher wages. ${ }^{16}$ People invest more in raising the human capital of their children even as family size shrinks. A shrinking workforce, while it increases the capital intensity in the short run, ultimately leads to lower investment as capital needs decline. What poses a challenge for Singapore is that an economy with an older age structure appears to generate slower productivity growth. ${ }^{17}$ One reason is that the lower labour force participation rate among older workers limits the extent of knowledge transfer from older and more experienced workers to younger workers. Another reason is that the pace of innovation tends to slow down due to a decline in the supply of entrepreneurs. To generate economic prosperity in the mature phase, Singapore will have to adopt a twopronged approach to boost total fertility and manage a controlled inflow of immigrants to keep the population from shrinking.

The Singapore economy has transited from a phase of growth when the efficiency-equity frontier moved favourably to another phase of growth when a given level of equity corresponds to slower economic growth. What is needed now is to develop a system of social insurance that is fiscally sustainable. A political equilibrium must be achieved that would allow an increase in the supply of entrepreneurs to develop indigenous innovation in the face of the declining citizen population. Productivity growth driven by indigenous innovation is needed to provide the fiscal resources to lift up the pay rate of the economically disadvantaged. An innovative economy also facilitates social mobility if the state invests in raising the cognitive and noncognitive abilities of children from disadvantaged families and expose them to role models of successful innovators. By providing them a

\footnotetext{
${ }^{16}$ See Gary S. Becker, 1991, A Treatise on the Family, enlarged edition, Cambridge, MA: Harvard University Press.

${ }^{17}$ See Nicole Maestas, Kathleen J. Mullen, and David Powell, 2016, "The Effect of Population Aging on Economic Growth, the Labor Force and Productivity," NBER Working Paper No. 22452.
} 
good chance of becoming successful innovators despite coming from low-income families, the index of social mobility can improve given the uncertainty inherent in new business ventures. ${ }^{18}$ Basic to gaining political support to embrace economic openness is the recognition that a social surplus is created when people with different abilities and skill levels specialise in activities in which they have comparative advantage.

The nature of what the good life is for an individual depends upon the type of society that the person lives in. In the first phase of growth, it was possible for workers across the whole skills distribution to hold jobs that delivered rising wages propelled by market forces until around 2000. Since then, policy intervention in the form of the Workfare Income Supplement scheme has been necessary to foster economic inclusion. The next phase of growth requires indigenous innovation that is likely to come along with greater creative destruction and more frequent disruptions to jobs and wages. It is, nevertheless, still possible to envision careers that are fulfilling if the economy generates for each individual the potential to achieve his or her dreams. Such an economy is apt to be one that is dynamic and inclusive even though individuals can expect to face more transitions in their career over a lifetime.

\footnotetext{
${ }^{18}$ Alex Bell, Raj Chetty, Xavier Jaravel, Neviana Petkova, and John Van Reneen, 2017, "Who Becomes an Inventor in America? The Importance of Exposure to Innovation," NBER Working Paper No. 24062.
} 